\title{
Individual variation in advertisement calls of the pale-shouldered horned toad (Xenophrys boettgeri)
}

\author{
Li Wei $^{1} \cdot$ Cuntong Zhou ${ }^{2} \cdot$ Weiwei Shao ${ }^{1} \cdot$ Huanzong Lei ${ }^{1} \cdot$ Zhihua Lin $^{1}$
}

Received: 6 December 2018 / Revised: 31 July 2019 / Accepted: 9 August 2019/Published online: 23 August 2019

(C) The Author(s) 2019

\begin{abstract}
The characteristics of male anurans' calls play an important role in mating success during the breeding season. In this study, we analyzed intra- and inter-individual variability of the advertisement calls of the pale-shouldered horned toad (Xenophrys boettgeri) in the field during its breeding season in Lishui, Zhejiang Province, China. The results showed that some acoustic parameters were significantly correlated with morphological features and air temperature. Most acoustic parameters including note numbers, call duration, and dominant frequency were static, whereas the call interval was intermediate. $\mathrm{The}_{\mathrm{CV}} / \mathrm{CV}_{\mathrm{w}}$ ratio was greater than 1.0 for all acoustic parameters analyzed, with between-individual variation being higher than within-individual variation. Furthermore, the acoustic parameter results of principle component analysis and discriminant function analysis indicated that note numbers and call interval are potentially useful for individual discrimination of $X$. boettgeri.
\end{abstract}

Keywords Anura $\cdot$ Advertisement call $\cdot$ Call variability $\cdot$ Individual differences $\cdot$ Xenophrys boettgeri

\section{Introduction}

In anurans, species recognition and female preference typically depend on acoustic signals (Rodríguez-Tejeda et al. 2014; Toledo et al. 2015; Forti et al. 2016; Viuchelozano et al. 2018). Five typical kinds of vocalization namely reciprocation calls, release calls, distress calls, territorial calls, and advertisement calls (Bee and Perrill 1996) play important roles in the social context of this species, including in territory defense, mating attraction, breeding status, and predation alarms (Batista et al. 2015; Toledo et al. 2015; Galvis et al. 2016; Guerra et al. 2017). Of these, advertisement calls have been widely studied because they characterize species-specific courtship signals (Chuang et al. 2016; Da Veiga Teixeira et al. 2016; Galvis et al. 2016; Modak et al. 2016; Serrano 2016; Bosch et al. 2017). Male anurans emit a unique advertisement call to enable females to identify and evaluate conspecific males (Grenat et al. 2013; Twomey et al. 2015; Protázio et al.

Zhihua Lin

zhlin1015@126.com

1 College of Ecology, Lishui University, Lishui 323000, Zhejiang, China

2 College of Life Sciences, Nanjing Normal University, Nanjing 210046, Jiangsu, China
2017), and female anurans often decide what male to mate based on the quality and structure of these calls (Pröhl 2003; Yu and Zheng 2009; Welch et al. 2014). Generally, males who produce calls of lower frequencies, higher rates, longer durations, greater intensities, and greater complexity are more favorable as mates (Bee et al. 1999; Pröhl 2003; Morais et al. 2012; Batista et al. 2015). In previous studies, long call duration has been viewed as a "good gene indicator" in the female choice model of sexual selection, which predicts that female mate choice is based on some aspect of male behavior or morphology that indicates male quality (Welch et al. 1998; Doty and Welch 2001; Gingras et al. 2013a, b; Welch et al. 2014). Given the species-specific properties of anuran advertisement calls, they have been used as a diagnostic tool to resolve taxonomic problems (Wang et al. 2014; Twomey et al. 2015; Galvis et al. 2016; Rivera-Correa et al. 2017). Because advertisement calls are distinctive, they are also of widespread interest in studies of phylogeography (Baraquet et al. 2015; Shen et al. 2015; Lee et al. 2016; Forti et al. 2016) and evolution (Brusa et al. 2013; Kaefer et al. 2013). However, the characteristics of advertisement calls are easily influenced by biotic and abiotic factors such as air temperature, body temperature, body size and weight, and social context (Gingras et al. 2013a, b; Gambale and Bastos 2014; Toledo et al. 2015). Other biotic processes, like interspecific acoustic interactions, which generate distinctive background 
noise, can affect call variation among populations (Höbel and Gerhardt 2003; Booman and Kurniati 2011; Xiong et al. 2015). Therefore, sexual selection and environmental conditions may result in variation in advertisement call characteristics among individuals and populations (Shen et al. 2015; Forti et al. 2016; Lee et al. 2016; Bosch et al. 2017).

Several previous studies have documented that anuran vocalization behavior exhibits a continuum of variation, which ensures the recognition of conspecific calls and enables discrimination between individuals (Bee et al. 2001; Gasser et al. 2009; Rodríguez et al. 2010; Gambale et al. 2014; Arini et al. 2016; Bosch et al. 2017). There are three levels of variation in call properties: within a single individual, among individuals of the same species, and among individuals of different species (Gerhardt 1991; Gambale et al. 2014). Variation in call properties between individual conspecific males may provide effective cues for female choice, whereas variation at the species level may be investigated from an evolutionary perspective with regard to choruses (Searcy and Nowicki 2005; Gambale et al. 2014; Guerra et al. 2017). Based on the different levels of variation, acoustic properties are categorized as static or dynamic. Static properties have low levels of withinindividual variation (usually $<5 \%$ ) and tend to be under stabilizing or weakly directional selection. By contrast, dynamic properties exhibit high levels of within-individual variation (> $12 \%$ ) and tend to be under directional selection (Arini et al. 2016; Bosch et al. 2017). Static properties (e.g., dominant frequency) are more likely to be used for species recognition because the values are at or near the population mean (Pettitt et al. 2013), whereas dynamic properties (e.g., call duration) can potentially be used to determine individual identity because of the high level of among-individual variation (Bee et al. 2001; Gambale et al. 2014). Call signals change along the continuum from static to dynamic due to different selection pressures on the vocalizations (Rodríguez et al. 2010; Gambale et al. 2014; Guerra et al. 2017). Therefore, for individual signal distinctiveness, it is necessary that the acoustic variability among individuals of a species is greater than that within individuals (Gerhardt 1991; Pröhl 2003; Gambale et al. 2014; Guerra et al. 2017).

The horned toad Xenophrys boettgeri (previously known as Megophrys boettgeri) is distributed mainly in west, southwest, south, central, and east China (Fei et al. 2012) where it occurs around streams (Wang et al. 2014). Although the advertisement calls of this species were briefly reported by Wang et al. (2014), they have not been well described. In the present study, we recorded and analyzed the advertisement calls of $X$. boettgeri from Baishanzu Mountain National Nature Reserve, Zhejiang Province, China, during its breeding season. Our aims were (1) to analyze patterns of variability in the advertisement calls of $X$. boettgeri and (2) to confirm whether acoustic properties of calls produced by $X$. boettgeri are effective for distinguishing individuals.

\section{Materials and methods}

Field work was performed along streams within the Baishanzu Mountain National Nature Reserve, Zhejiang Province, China, from 2 to 10 July $2016\left(120^{\circ} 34.965^{\prime} \mathrm{E}, 28^{\circ} 32.972^{\prime} \mathrm{N}\right)$ during breeding season. The area was searched from 20:00 until 23:00 $\mathrm{h}$ for male frogs emitting advertisement calls, with great care taken not to disturb the individuals being recorded. An external directional microphone was held approximately 1-2 $\mathrm{m}$ from each toad to record any calls made on a Sony IC recorder (ICD-SX2000) with a sampling frequency of 44,100 $\mathrm{Hz}$ and 16-bit resolution. The calls from each toad were recorded for a range of 3 to $5 \mathrm{~min}$. We captured the male toad immediately after the recording session and measured its body length (snout vent length, SVL) to the nearest $0.1 \mathrm{~mm}$ using a dial caliper (Shanghai Medical Laser Company) and body mass to the nearest $0.001 \mathrm{~g}$ using an electric scale (Jinnuo Balance Instrument Co., Ltd., Jinhua, China). Air temperature was monitored approximately $5 \mathrm{~cm}$ above the ground where the toad was captured using a thermometer (HOBO U12-008, USA).

All recordings were run through Cool Edit PRO (Syntrillium Software Corporation, USA) to reduce any background noise and then saved in .wav format. Calls were analyzed using Praat (version 6.0.12). Call parameters were defined and illustrated based on the methods described by Bee et al. (2001), Gambale et al. (2014), and Bosch et al. (2017). The dominant frequency was measured from spectrum window moving cursor to nearest peak under total bandwidth $22,050 \mathrm{~Hz}$. Ten calls in each call sequence within a sound file were analyzed, and the following call properties were measured: note numbers $(\mathrm{NN})$, call duration $(\mathrm{CD} / \mathrm{s})$, call interval $(\mathrm{CI} / \mathrm{s})$, and dominant frequency $(\mathrm{DF} / \mathrm{Hz})$.

To evaluate call variability patterns within and among individuals, the coefficient of variation for each acoustic parameter was calculated using the following formula: standard deviation $(\mathrm{SD} /$ mean $) \times 100 \%$. Within-male coefficients of variation $\left(\mathrm{CV}_{\mathrm{w}}\right)$ were calculated from the means and SDs of calls produced by each individual. Consistent with previous studies, if the $\mathrm{CV}_{\mathrm{w}}$ of a given call property was less than 5\%, it was identified as "static" as there was little variation between calls; conversely, call properties were identified as "dynamic" when the $\mathrm{CV}_{\mathrm{w}}$ was greater than $12 \%$. In cases where $\mathrm{CV}_{\mathrm{w}}$ was between 5 and $12 \%$, the call property was identified as "intermediate" (Gasser et al. 2009; Gambale et al. 2014). Between-male coefficients of variation $\left(\mathrm{CV}_{\mathrm{b}}\right)$ were calculated from the grand mean and SD. The ratio of between-male to within-male coefficients of variation $\left(\mathrm{CV}_{\mathrm{b}}\right)$ $\mathrm{CV}_{\mathrm{w}}$ ) was calculated as a measure of relative between-male variability. If the ratio of $\mathrm{CV}_{\mathrm{b}} / \mathrm{CV}_{\mathrm{w}}$ for a given call property was > 1.0 , the property can be seen as more variable between individuals and potentially identified as a recognition cue facilitating communication between individuals (Bee et al. 2001; Gasser et al. 2009; Pettitt et al. 2013; Bosch et al. 2017). 
Fig. 1 Advertisement calls of Xenophrys boettgeri:

oscillograms of a sequence of 5 calls (a); oscillogram of the notes composing one call in the frame from a (b); power spectrum of one call $(\mathbf{c})$

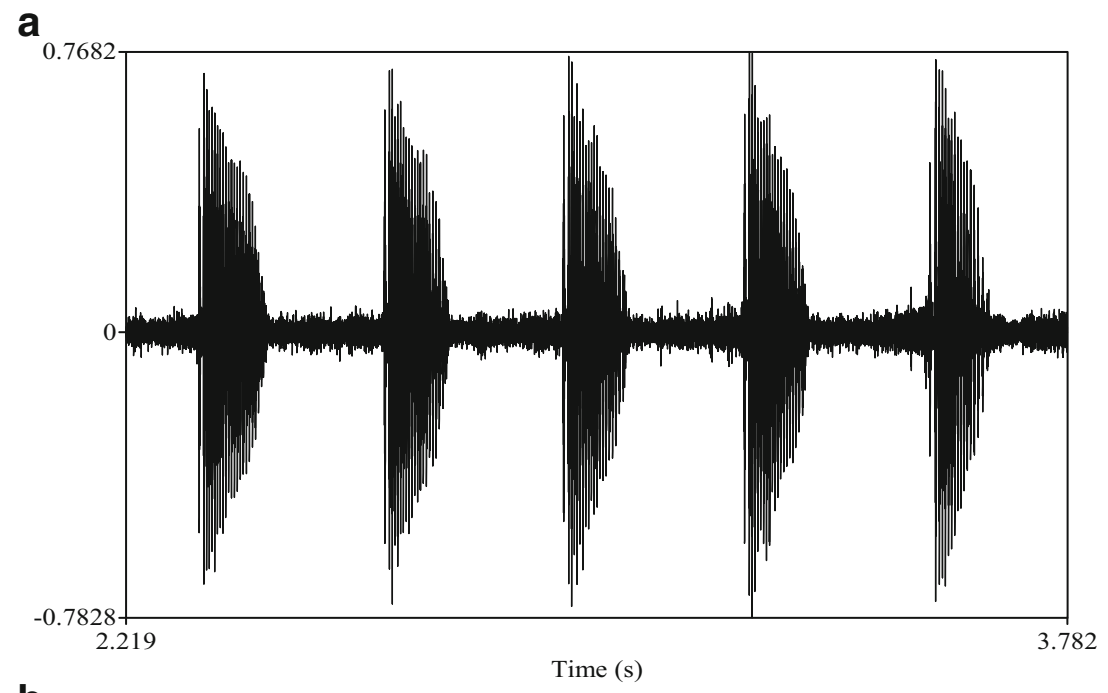

b
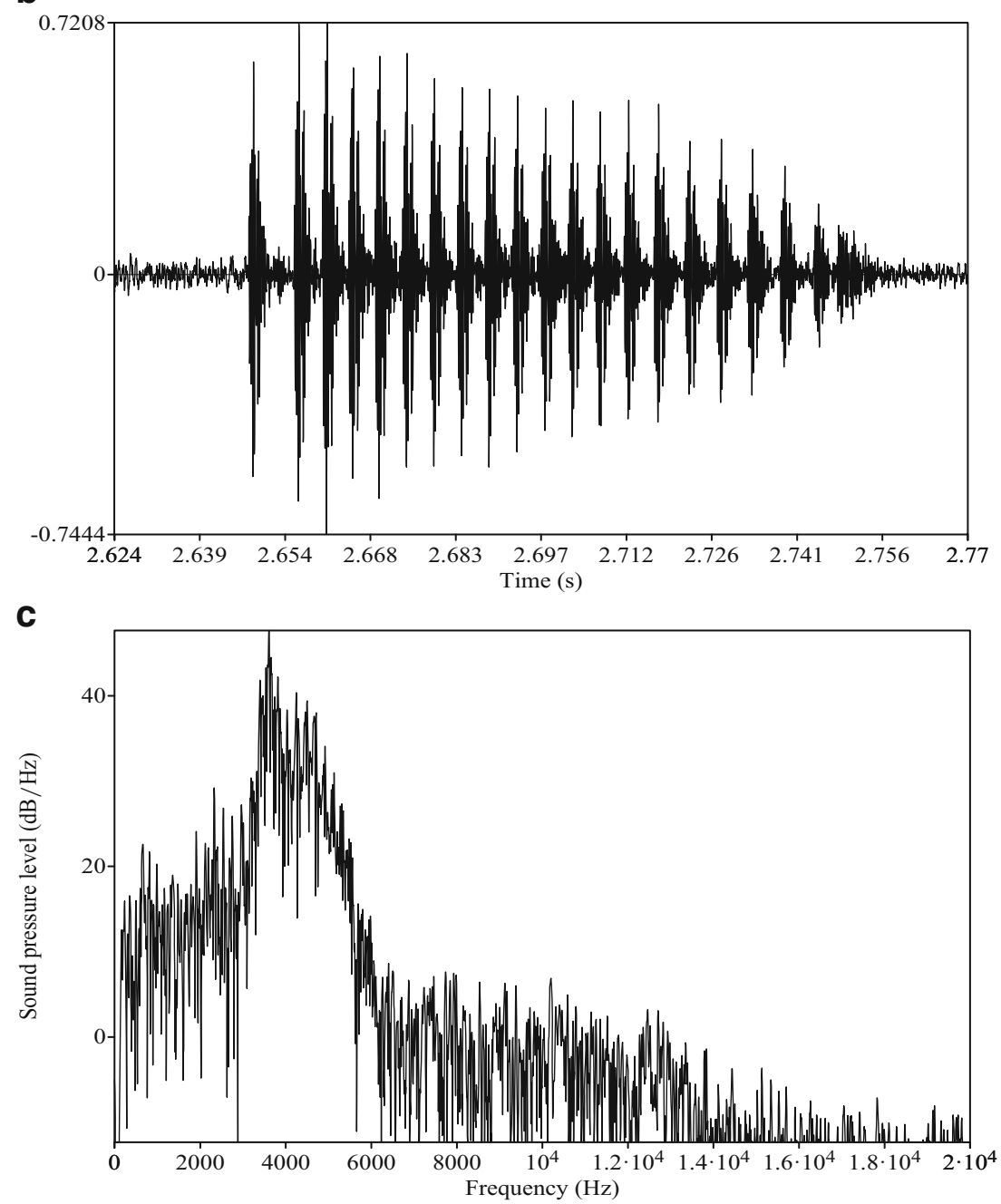

The results are presented as mean \pm SD. To estimate whether the observed variability in call properties differed significantly among males, one-way analysis of variance was conducted (Gasser et al. 2009). The Pearson rank coefficient was used to test the correlations between pairwise call properties, and between call properties and SVL, body mass, and air temperature.

To determine whether acoustic parameters of $X$. boettger $i$ could be used to distinguish individuals, a discriminant 
function analysis (DFA) was performed. Prior to DFA, we reduced the dimensionality of the data using a principal component analysis (PCA). The first three PCA scores were used as input variables for the DFA, following the methods described by Guerra et al. (2017). The level of statistical significance for all tests was set at $P=0.05$.

Prior to statistical analysis, all data were tested for normality (Kolmogorov-Smirnov test) and homogeneity of variances. The statistics analyses were similar to those described by Gasser et al. (2009), Gambale et al. (2014), and Bosch et al. (2017) and performed using SPSS 16.0 software (IBM) for windows.

\section{Results}

In total, 130 calls from 13 male $X$. boettgeri were recorded and analyzed. The 13 males had a SVL of $32.0 \pm 1.6 \mathrm{~mm}$ and mass of $2.413 \pm 0.567 \mathrm{~g}$. The air temperature at the time of recording was $24.3 \pm 2.7^{\circ} \mathrm{C}$.

The advertisement calls comprised multi-notes with no harmonic structure (Fig. 1). Analysis of the 130 calls resulted in a note number of $16.9 \pm 1.7$ (range 10-22), call duration of 0.086 $\pm 0.009 \mathrm{~s}$ (range $0.061-0.110 \mathrm{~s}$ ), and call interval of $0.218 \pm$ 0.057 (range $0.068-0.415 \mathrm{~s}$ ). The dominant frequency was $3543.46 \pm 156.74 \mathrm{~Hz}$ (range $3081.33-4226.75 \mathrm{~Hz}$ ). After comparisons, we found all these acoustic parameters were significantly different among the 13 males (one-way ANOVA) (Table 1).

Regarding within-individual variation $\left(\mathrm{CV}_{\mathrm{W}}\right)$, we found that note number, call duration, and dominant frequency were static, whereas call interval was intermediate (Table 1). Regarding between-individual variation $\left(\mathrm{CV}_{\mathrm{b}}\right)$, with the exceptions of call interval, which was dynamic, all other call parameters were intermediate or static (Table 1).

Some significant correlations were found between call properties and between call properties and SVL, body mass, and air temperature (Table 2). Call interval was negatively correlated with SVL and body mass, whereas note number was positively correlated with body mass (Table 2).

In the PCA, the first three principal components accounted for $89.3 \%$ of the variation (Table 3 ). PCA1 axis
Table 2 Pearson product moment correlations $(r)$ between mean values of each call parameter and between call parameters and body mass, SVL, and air temperature $(n=13)$. $N N$ note numbers in a call, $C D$ call duration, $C I$ call interval, $D F$ dominant frequency, $S V L$ snout-vent length, $B M$ body mass, $A T$ air temperature

\begin{tabular}{lllll}
\hline & $\mathrm{NN}$ & $\mathrm{CD}$ & $\mathrm{CI}$ & $\mathrm{DF}$ \\
\hline $\mathrm{NN}$ & & & & \\
$\mathrm{CD}$ & 0.358 & & & \\
$\mathrm{CI}$ & -0.340 & 0.298 & & \\
$\mathrm{DF}$ & -0.198 & -0.124 & -0.018 & \\
$\mathrm{BM}$ & $0.672^{*}$ & 0.085 & $-0.653^{*}$ & -0.147 \\
$\mathrm{SVL}$ & 0.517 & 0.026 & $-0.599^{*}$ & -0.057 \\
AT & -0.414 & -0.335 & 0.506 & -0.015 \\
\hline
\end{tabular}

*Significant correlation

explained $35.8 \%$ of the total variation and was mostly influenced by note number (factor score $=-0.822$ ) and call duration (factor score $=-0.779$ ) call intensity; PCA2 axis was influenced by call interval (factor score $=-0.945$ ), which explained $29.7 \%$ of the variance; and PCA3 axis was influenced by dominant frequency (factor score $=$ 0.9220 ), which explained $23.8 \%$ of the variance (Table 3 ). The first three PCA scores were then used as input for DFA. Three discriminant functions (DFun) were generated, and the first two discriminant functions had eigenvalues above 1.0 , explaining $93.4 \%$ of the total variation. The first DFun was represented by PCA1 (eigenvalue of 5.573) and explained $59.2 \%$ of the variation. The second DFun was represented by PCA2 (eigenvalue of 3.216) and explained $34.2 \%$ of the variation, and the third DFun was represented by PCA3 (eigenvalue of 0.616 ) and explained $6.6 \%$ of the variation. The Wilks Lambda values of DFun1 (Wilks $\lambda=$ 0.022 ) and DFun2 (Wilks $\lambda=0.146$ ) were close to 0 ( $<$ 0.01 ), indicating that the variables PCA1 (note number) and PCA2 (call interval) were appropriate for discriminating males. The percentage of cases correctly classified was $70.8 \%$ (Fig. 2).

Table 1 Variability of acoustic properties of advertisement calls in different individuals of male Xenophrys boettgeri $(n=13)$. NN note numbers in a call, $C D$ call duration, $C I$ call interval, $D F$ dominant frequency

\begin{tabular}{|c|c|c|c|c|c|c|c|c|c|}
\hline Parameters & Grand mean $\pm \mathrm{SD}$ & Range & $\begin{array}{l}\text { Mean } \\
\text { within- } \\
\text { male CV }\end{array}$ & $\begin{array}{l}\text { Range of } \\
\text { within-male } \\
\text { CV }\end{array}$ & $\begin{array}{l}\text { Between- } \\
\text { male CV }\end{array}$ & $\begin{array}{l}\text { Maximum } \\
\text { between-male } \\
\text { difference }\end{array}$ & $\begin{array}{l}\text { Ratio } \\
\mathrm{CV}_{\mathrm{b}} / \\
\mathrm{CV}_{\mathrm{w}}\end{array}$ & $\begin{array}{l}\text { One-way } \\
\text { ANOVA }\end{array}$ & Type \\
\hline $\mathrm{NN}$ & $16.9 \pm 1.71$ & $10-22$ & $5.36 \%$ & $2.25-15.15 \%$ & $10.12 \%$ & $72.41 \%$ & 1.89 & $F_{12,117}=24.790 *$ & Static \\
\hline $\mathrm{CD} / \mathrm{s}$ & $0.086 \pm 0.009$ & $0.061-0.110$ & $3.64 \%$ & $1.74-5.64 \%$ & $10.47 \%$ & $48.57 \%$ & 2.88 & $F_{12,117}=58.680^{*}$ & Static \\
\hline $\mathrm{CI} / \mathrm{s}$ & $0.218 \pm 0.057$ & $0.068-0.415$ & $10.28 \%$ & $2.38-32.62 \%$ & $26.15 \%$ & $146.47 \%$ & 2.54 & $F_{12,117}=30.905^{*}$ & Intermediate \\
\hline $\mathrm{DF} / \mathrm{Hz}$ & $3543.46 \pm 156.74$ & $3081.33-4226.75$ & $2.67 \%$ & $0.83-8.72 \%$ & $4.42 \%$ & $12.67 \%$ & 1.66 & $F_{12,117}=6.200 *$ & Static \\
\hline
\end{tabular}

* Significant differences, $P<0.05$ 
Table 3 Results from principal component analysis of advertisement call parameters of Xenophrys boettgeri. $N N$ note numbers in a call, $C D$ call duration, $C I$ call interval, $D F$ dominant frequency. Coefficients with largest values for each factor is in italics

\begin{tabular}{llll}
\hline \multirow{2}{*}{ Acoustic parameters } & \multicolumn{2}{l}{ PCA factor } & \\
\cline { 2 - 4 } & Factor 1 & Factor 2 & Factor 3 \\
\hline $\mathrm{NN}$ & -0.822 & 0.359 & 0.170 \\
$\mathrm{CD}$ & -0.779 & -0.407 & 0.273 \\
$\mathrm{CI}$ & 0.041 & -0.945 & -0.010 \\
$\mathrm{DF}$ & 0.382 & 0.044 & 0.922 \\
Eigenvalue & 1.431 & 1.189 & 0.953 \\
Variance (\%) & $35.8 \%$ & $29.7 \%$ & $23.8 \%$ \\
Cumulative variance (\%) & $35.8 \%$ & $65.5 \%$ & $89.3 \%$ \\
\hline
\end{tabular}

\section{Discussion}

Most anurans utilize acoustic signals to convey messages during their life history (Gambale et al. 2014; Guerra et al. 2017). In the present study, we recorded and analyzed the advertisement calls of $X$. boettgeri from their breeding chorus arenas. This species produces multi-note calls within a bout containing shallow or no frequency modulation. The call structure is similar to that of sibling species in the genus Xenophrys (Wang et al. 2014; Xiong et al. 2015).

Previous studies have documented that environmental temperature, morphological features, and social context can influence acoustic properties (Morais et al. 2012; Gingras et al. 2013a, b; Gambale et al. 2014). We also found that morphological features (SVL and body mass) significantly affected both temporal parameters (call interval, note number). Call duration and dominant frequency were not influenced by air temperature or morphology, which indicates they are relatively stable over time within a population (Gambale et al. 2014). A previous study of the advertisement calls of $X$. boettgeri was based on fewer recordings $(n=3)$ at a lower environmental temperature $\left(15^{\circ} \mathrm{C}-\right.$ $18{ }^{\circ} \mathrm{C}$ ), which could affect the assessment of bioacoustic variability of this species (Wang et al. 2014). However, the call duration and note number were higher in the study by Wang et al. (2014) than in our data, suggesting geographic variation in some acoustic parameters among different populations. Similar patterns have been reported in other anuran species including Bufo melanostictus (Wei et al. 2012), Hypsiboas cordobae (Baraquet et al. 2015), and Paa spinosa (Shen et al. 2015). The dominant frequency was similar between our study and that of Wang et al. (2014), indicating that this stable acoustic parameter can be used to distinguish the species of Xenophrys (Wang et al. 2014). Similar results are also found in other closely related anuran species, for example, Pristimantis (Padial and De la Riva 2009) and Physalaemus (Guerra et al. 2017).

Acoustic properties are classified as dynamic, intermediate, or static based on the level of variability (Gerhardt 1991; Bee et al. 2001; Pröhl 2003; Gambale et al. 2014; Arini et al. 2016). In $X$. boettgeri, considering within-individual variation, most acoustic properties (note number, call duration, and dominant frequency) were static, whereas call interval was intermediate. When considering between-individual variation, with the exceptions of dominant frequency (which were static), all other properties were intermediate and/or dynamic. Moreover, the $\mathrm{CV}_{\mathrm{b}} / \mathrm{CV}_{\mathrm{w}}$ ratio was above 1.0 for all acoustic parameters analyzed, with between-individual variation being higher than withinindividual variation. This is in agreement with findings for other anuran species that variability of acoustic properties between individuals can be used as a recognition cue for individual discrimination (Pröhl 2003; Gasser et al. 2009; Padial and De la Riva 2009; Pettitt et al. 2013; Gambale et al. 2014; Arini et al. 2016; Guerra et al. 2017).
Fig. 2 Scatterplot of advertisement calls of Xenophrys boettgeri along the first two acoustic principle component factors. 1-13 indicated the 13 male individuals respectively

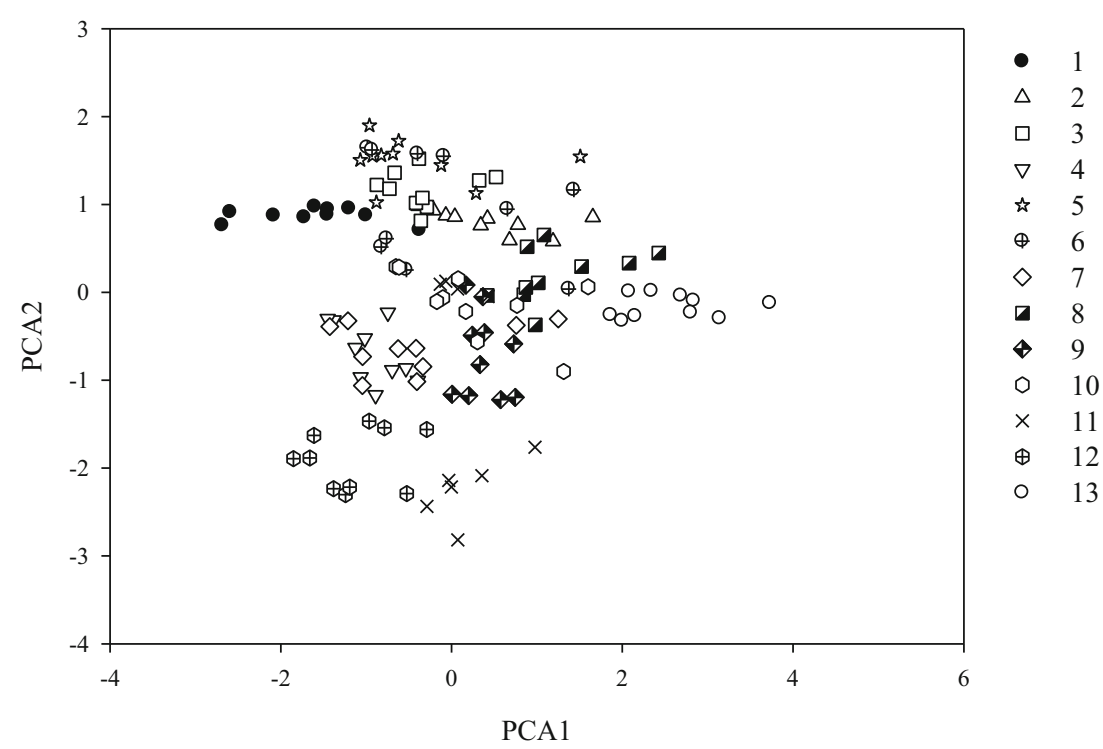


Some acoustic properties of calls emitted by frogs and toads are sufficient to determine individuality (Bee et al. 2001; Pettitt et al. 2013; Gambale et al. 2014; Arini et al. 2016). Male $X$. boettgeri in this study showed higher acoustic variation between individuals than within individuals, which might indicate genetic divergence, different adopted tactics, and directional sexual selection (Morais et al. 2012; Velásquez et al. 2013; Guerra et al. 2017). This pattern has also been found in the anuran species Allobates femoralis (Gasser et al. 2009), Xenopus (Evans et al. 2015), and Proceratophrys moratoi (Forti et al. 2016). As found in the present study, note number and call interval of $X$. boettgeri are potentially useful for individual discrimination. These call parameters, selected by DFun 1, and DFun 2, that showed relatively higher between-male variation were also those with a higher $\mathrm{CV}_{\mathrm{b}} / \mathrm{CV}_{\mathrm{w}}$. However, both temporal (e.g., call duration) and spectral parameters (e.g., dominant frequency) have been reported to be important traits for individual distinctiveness in other species (Gasser et al. 2009; Morais et al. 2012; Gambale et al. 2014; Guerra et al. 2017).

Xenophrys boettgeri lives alongside streams, and the males call in separate locations. As a result, this requires the species faces interference from background noise of the stream and must produce special acoustic signals (e.g., higher dominant frequency, longer call duration, stronger call intensity, higher pulse rate) to avoid environmental disturbance when advertising for a mate (Feng et al. 2009; Shen et al. 2011). Calling in separation may reduce competition with other males for female attraction but increases predation risk because the calling individual is easy to locate (Wells 2007). Therefore, it is important that vocalization contributes to individual discrimination (Guerra et al. 2017).

Acknowledgments The anonymous referees provided helpful insights and comments on the paper.

Funding information This study was supported by the Natural Science Foundation of Zhejiang, China (LY19C040001), and the Key Research Projects of Lishui City (20151206, SH2017001).

Open Access This article is distributed under the terms of the Creative Commons Attribution 4.0 International License (http:// creativecommons.org/licenses/by/4.0/), which permits unrestricted use, distribution, and reproduction in any medium, provided you give appropriate credit to the original author(s) and the source, provide a link to the Creative Commons license, and indicate if changes were made.

\section{References}

Arini K, Noer MI, Wulandari A, Amalia R, Auliandina T (2016) Temporal and spectral variation in advertisement call of males Microhyla achatina (Tschudi, 1838) are sufficient for individual discrimination. AIP Conf Proc 1744:020032
Baraquet M, Grenat PR, Salas NE, Martino AL (2015) Geographic variation in the advertisement call of Hypsiboas cordobae (Anura, Hylidae). Acta Ethol 18:79-86

Batista VG, Gambale PG, Lourenço-de-Moraes R, Campos RM, Bastos RP (2015) Vocalizations of two species of the Hypsiboas pulchellus group (Anura: hylidae) with comments on this species group. NorthWestern J Zool 11:253-261

Bee MA, Perrill S (1996) Responses to conspecific advertisement calls in the green frog (Rana clamitans) and their role in male-male communication. Behavour 133:283-301

Bee MA, Perrill SA, Owen PC (1999) Size assessment in simulated territorial encounters between male green frogs (Rana clamitans). Behav Ecol Sociobiol 45:177-184

Bee MA, Kozich CE, Blackwell KJ, Gerhardt HC (2001) Individual variation in advertisement calls of territorial male green frog, Rana clamitans: implications for individual discrimination. Ethology 107: 65-84

Booman A, Kurniati H (2011) Evolution of high-frequency communication in frogs. Evol Ecol Res 13:197-207

Bosch RA, Rodriguez A, Quinta MH (2017) Advertisement call variation and individual acoustic distinctiveness in the explosive breeding toad Peltophryne cataulaciceps (Anura: Bufonidae). Acta Ethol 20:197-205

Brusa O, Bellati A, Meuche I, Mundy NI, Pröhl H (2013) Divergent evolution in the polymorphic granular poison-dart frog, Oophaga granulifera: genetics, coloration, advertisement calls and morphology. J Biogeogr 40:394-408

Chuang MF, Kam YC, Bee MA (2016) Quantitative description of the vocal repertoire of the territorial olive frog Babina adenopleura from Taiwan. Bioacoustics 25(1):1-18

Doty GV, Welch AM (2001) Advertisement call duration indicates good genes for offspring feeding rate in gray tree frogs (Hyla versicolor). Behav Ecol Sociobiol 49:150-156

Evans BJ, Carter TF, Greenbaum E, Gvoždík V, Kelley DB, McLaughlin PJ, Pauwels OSG, Portik DM, Stanley EL, Tinsley RC, Tobias ML, Blackburn DC (2015) Genetics, morphology, advertisement calls, and historical records distinguish six new Polyploid species of African clawed frog (Xenopus, Pipidae) from West and Central Africa. PLoS One 10(12):e0142823

Fei L, Ye CY, Jiang JP (2012) Colored atlas of Chinese amphibians and their distributions. Sichuan Publishing House of Science and Technology, Chengdu

Feng AS, Riede T, Arch VS, Yu Z, Xu ZM, Yu XJ, Shen JX (2009) Diversity of the vocal signals of concave eared torrent frogs (Odorrana tormota): evidence for individual signatures. Ethology 115:1015-1028

Forti LR, Costa WP, Maryins LB, Nunes-de-Almeida CHL, Toledo LF (2016) Advertisement call and genetic structure conservatism: good news for an endangered Neotropical frog. PeerJ 4:e2014

Galvis PA, Caorsi VZ, Sánchez-Pacheco SJ, Rada M (2016) The advertisement calls of three hylid frogs from Hispaniola. Bioacoustics 25(1):89-97

Gambale PG, Bastos RP (2014) Vocal repertoire and bioacoustic analyses in Physalaemus cuvieri (Anura: Leptodactylidae) in southern Brazil. Herpetol J 24:31-39

Gambale PG, Signorelli L, Bastos RP (2014) Individual variation in the advertisement calls of a Neotropical treefrog (Scinax constrictus). Amphibia-Reptilia 35:271-281

Gasser H, Amézquita A, Hödl W (2009) Who is calling? Intraspecific call variation in the Aromobatid frog Allobates femoralis. Ethology 115: 596-607

Gerhardt HC (1991) Female mate choice in treefrogs: static and dynamic acoustic criteria. Anim Behav 42:615-635

Gingras B, Boeckle M, Herbst CT, Fitch WT (2013a) Call acoustics reflect body size across four clades of anurans. J Zool 289:143-150 
Gingras B, Mohandesan E, Boko D, Fitch WT (2013b) Phylogenetic signal in the acoustic parameters of the advertisement calls of four clades of anurans. BMC Evol Biol 13:134

Grenat PR, Valetti JA, Martino AL (2013) Intra-specific variation in advertisement call of Odontophrynus cordobae (Anura, Cycloramphidae): a multilevel and multifactor analysis. AmphibiaReptilia 34(4):471-482

Guerra V, de Morais AR, Gambale PG, Oda FH, Bastos RP (2017) Variation of the advertisement call of Physalaemus centralis Bokermann, 1962 (Anura: Leptodactylidae) in the Cerrado of Central Brazil. Stud Neotrop Fauna Environ 52(2):103-111

Höbel G, Gerhardt HC (2003) Reproductive character displacement in the acoustic communication system of green tree frogs (Hyla cinerea). Evolution 57(4):894-904

Kaefer IL, Tsuji-Nishikido BM, Mota EP, Farias IP, Lima AP (2013) The early stages of speciation in Amazonian forest frogs: phenotypic conservatism despite strong genetic structure. Evol Biol 40(2): 228-245

Lee KH, Shaner PJL, Lin YP, Lin SM (2016) Geographic variation in advertisement calls of a microhylid frog-testing the role of drift and ecology. Ecol Evol 6(10):3289-3298

Modak N, Dahanukar N, Ogale H, Padhye A (2016) Advertisement calls of Amboli leaping frog Indirana chiravasi (Anura: Ranixalidae) from northern Western Ghats, India. Curr Sci 110(12):2220-2223

Morais AR, Batista VG, Gambale PG, Signorelli L, Bastos RP (2012) Acoustic communication in a Neotropical frog (Dendropsophus minutus): vocal repertoire, variability, and individual discrimination. Herpetol J 22:249-257

Padial JM, De la Riva I (2009) Integrative taxonomy reveals cryptic Amazonian species of Pristimantis (Anura). Zool J Linnean Soc 155:97-122

Pettitt BA, Bourne GR, Bee MA (2013) Advertisement call variation in the golden rocket frog (Anomaloglossus beebei): evidence for individual distinctiveness. Ethology 119:244-256

Pröhl H (2003) Variation in male calling behaviour and relation to male mating success in the strawberry poison frog (Dendrobates pumilio). Ethology 109:273-290

Protázio ADS, Protázio ADS, Concleição LC, Braga HSE, Santos UGD, Ribeiro AC, Souza ICA (2017) The advertisement call of Dendropsophus novaisi (Bokermann, 1968) (Anura: Hylidae: Dendropsophinae). Zootaxa 4294(1):127-129

Rivera-Correa M, Vargas-Salinas F, Grant T (2017) Statistical differences and biological implications: a comparative analysis of the advertisement calls of two Andean stream treefrogs (Hylidae: Hyloscirtus) and the evolution of acoustic characters. Salamandra 53(2):237-244

Rodríguez A, De la Nuez D, Alonso R (2010) Intraspecific variation in the advertisement call of the cloud-forest frog Eleutherodactylus glamyrus (Anura: Eleutherodactylidae). J Herpetol 44:457-466

Rodríguez-Tejeda RE, Méndez-Cárdenas MG, Islas-Villanueva V, Garcial CM (2014) Geographic variation in the advertisement calls of Hyla eximia and its possible explanations. PeerJ 2:e420

Searcy WA, Nowicki S (2005) The evolution of animal communication. Reliability and deception in signaling systems. Monographs in Behavior and Ecology. Princeton University Press, New Jersey
Serrano JM (2016) The advertisement call of the endemic frog from the Pedregal in Mexico City. Rev Mex Biodivers 87(2):535-539

Shen JX, Xu ZM, Feng AS, Narins PM (2011) Large odorous frogs (Odorrana graminea) produce ultrasonic calls. J Comp Physiol A 197:1027-1030

Shen B, Chen P, Zheng RQ, Min JJ, Dong BJ, Zhao MM (2015) Geographic variation in the advertisement calls of the giant spiny frog (Paa spinosa). Acta Ecol Sin 35(1):39-45

Toledo LF, Martins IA, Bruschi DP, Passos MA, Alexandre C, Haddad CFB (2015) The anuran calling repertoire in the light of social context. Acta Ethol 18(2):87-99

Twomey E, Mayer M, Summers K (2015) Intraspecific call variation in the mimic poison frog Ranitomeya imitator. Herpetologica 71(4): $252-259$

da Veiga Teixeira BF, Zaracho VH, Giaretta AA (2016) Advertisement and courtship calls of Dendropsophus nanus (Boulenger, 1889) (Anura: Hylidae) from its type locality (Resistencia, Argentina). Biota Neotrop 16(4):e20160183

Velásquez NA, Marambio J, Brunetti E, Méndez MA, Vásquez RA, Penna M (2013) Bioacoustic and genetic divergence in a frog with a wide geographical distribution. Biol J Linn Soc 110:142-155

Viuchelozano A, Encisocalle MP, Bernal MH (2018) The advertisement call of Centrolene notostictum (Anura, Centrolenidae) with a new record of geographic distribution in Tolima, Colombia. Zootaxa 4377(4):575-576

Wang YY, Zhao J, Yang JH, Zhou ZX, Chen GL, Liu Y (2014) Morphology, molecular genetics, and bioacoustics support two new sympatric Xenophrys toads (Amphibia: Anura: Megophryidae) in Southeast China. PLoS One 9(4):e93075

Wei L, Zhao LH, Ma XH, Fan XL, Ma XM, Lin ZH (2012) Advertisement call variability in the black-spined toad Bufo melanostictus (Anura: Bufonidae) during the breeding season in Lishui, Zhejiang, China. Asian Herpetol Res 3(2):157-162

Welch AM, Semlitsch RD, Gerhardt HC (1998) Call duration as an indicator of genetic quality in male gray tree frogs. Science 280:19281930

Welch AM, Smith MJ, Gerhardt HC (2014) A multivariate analysis of genetic variation in the advertisement call of the gray treefrog, Hyla versicolor. Evolution 68(6):1629-1639

Wells KD (2007) The ecology and behavior of amphibians. The University of Chicago Press, Chicago (Il)

Xiong RC, Matui M, Nishikawa K, Jiang JP (2015) Advertisement calls of two horned frogs, Megophrys kuatunensis and M. huangshanensis, from China (Anura, Megophryidae). Curr Herpetol 34(1):51-59

Yu BG, Zheng RQ (2009) The advertisement call of the giant spiny frog Paa spinosa. Curr Zool 55:411-415

Publisher's note Springer Nature remains neutral with regard to jurisdictional claims in published maps and institutional affiliations. 